\title{
Stories from Palestine and Israel
}

Few could have watched the recent coverage of Gaza without feeling saddened and shocked. The most powerful stories, the ones which really connected with viewers and provided them with some understanding of what was happening, were those of ordinary people and families describing their experiences.

Our family visited the West Bank and Israel in November, before the war started, and heard many young people's stories which helped us towards some understanding of the persistent tension and the current conflict. Here are three.

The story of Aaron (not his real name), a young Israeli who loves his country but hates his government's treatment of the Palestinians and was hoping to avoid military service. But the call came. He hid from the Israeli Defence Force for 3 months, made use of the time studying psychiatric symptoms and treatment and then succeeded in convincing three psychiatrists that he was deeply depressed and could not be trusted with a gun. They exempted him but his life in Israeli society will now be difficult.

The second story is of Sara, the 19-yearold daughter of Israeli friends who is doing her national service and had, after the compulsory gun training, been working in a school for children with severe learning difficulties. When the war started she was deployed to one of the border towns to spend nights in an air-raid shelter comforting frightened children while feeling very vulnerable herself. Her parents were worried; what parents would not be? Her mother felt that the extent of the Israeli military response was necessary, I disagreed but I empathised with her concern for her daughter.

And the third story is of another 19-yearold, our daughter. We had been visiting friends in Jenin, in the north of the West Bank. Yousef runs a children's cultural centre, a place where local kids can go, play music, dance and learn, in a community which was shattered by the Israeli incursion in 2002 and which still shelters thousands of refugees. Afterwards we left to travel to Haifa in the north of
Israel and, 10 kilometres from Jenin, had to pass through a checkpoint. This is one of many Israeli military stations along the wall separating Israel from Palestine through which you have to pass to move between Israel and Palestine or vice versa. They are not inviting places. The concrete wall is 8 metres high and, as you enter the checkpoint, you are funnelled into a corridor bounded by concrete, metal and barbed wire.

Apart from an elderly Arab man in traditional garb and carrying a bag of oranges, we were alone. At least, we could not see anyone else. All we heard were voices coming from loudspeakers giving instructions, to the old man in Arabic, to us in English, 'Prepare your documents for inspection'. A few minutes later, 'Approach an inspection point when it becomes free'. We surrendered our bags and passports. The next stage was a metal and concrete cell with bare walls and a darkened glass window. Looking up, there were gangways running above the cell, patrolled by young soldiers pointing guns down towards us as they passed. The atmosphere was tense and unpleasant. We attempted to communicate with our Arab companion. He was resigned to the system; 'What can I do? What can I do?'

An amplified female voice coming from behind the screen told me and our 16-yearold daughter to move through a door, not to touch our bags which were on the floor and to wait. We did as instructed, leaving my husband and our 19-year-old daughter behind. 'Open the door on your left'; we moved through several other cells and found ourselves in a small hall with a small number of hard seats, a row of exit barriers adjacent to cubicles ahead of us and still the patrolling young soldiers above. The only information were signs saying, 'No smoking' and 'Keep the terminal clean'. We waited for 2 hours. No-one approached us or offered explanation for the delay of the rest of our family. I needed to go to the toilet and, after asking three times, was pointed towards a door which led outside to a barbed wire corridor with a portacabin at the end. As the door shut behind me I felt sudden worry that I would be separated from my daughter but pressing a button resulted in the door being opened and I was back with her in the 'terminal'.

By now, I was becoming anxious (and trying to hide it from her). My husband is asthmatic and suffers from claustrophobia and my older daughter, although of a calm temperament, was bound to be finding this difficult. Eventually, she appeared alone, struggling to control her tears, 'Where's dad?'

She had been kept in a cell alone. Three young women soldiers had entered and told her to take her clothes off for a strip search. She had argued for about a quarter of an hour, then had become upset and started to cry. They began to stroke her hair and said, 'Come on, you're coming to Israel. This is what happens'. At which point, she had become angry, and retorted, 'You're crazy'. They did not persist in trying to strip search her, but they left her alone in the small cell for another hour.

No wonder, when she emerged, she was upset. I felt extremely proud of her for standing her ground, and extremely unimpressed with the tourism strategy we seemed to be experiencing. After a further half hour, my husband appeared, having been kept in isolation and then strip searched. He had managed to keep panic at bay by methodically pacing up and down the cell, anxious that, if he were to have an asthma attack in this cell block guarded by bored young soldiers, no one might notice. He had asked the young soldier during the search if he enjoyed his job. 'This is Israel', again had come the reply.

The final stage was a further delay while the young officials asked my husband and daughter various questions (for example, 'What was your grandfather's first name?'), rang 'Tel Aviv', and finally, with no word of explanation or apology, said we could go.

Having been in the block for 4 hours, it was by then dark outside. We stood in the car park outside wondering what to do when the same young man who had strip searched my husband came outside, still with his inevitable gun but now wearing 
jeans and a baseball hat, and offered to ring for a taxi. We accepted the offer.

If we had known that our daughter would be subjected to such treatment, would we have taken a different route? Yes. Do we, and she, now regret not having done so? No. It had been a deeply unpleasant experience, but it is the sort of experience which many Palestinians, going about their daily lives, suffer routinely. Except they have no passports, no embassy to call, and no guarantee of eventual release. Gaining even a little insight into what that might feel like was invaluable and helped to make some sense of the personal stories behind the Palestine and Israel headlines more real.

\section{Lesley Morrison}

DOI: 10.3399/bjgp09X420158

\section{Caveat emptor}

The approval by the European Union for 'over-the-counter' (OTC) sale of the antiobesity drug orlistat (under the trade name alliø) has provoked another round of the familiar controversy over any attempt to reduce the medical profession's monopoly over the supply of drugs. Only a few weeks earlier there was a similar furore over pilot projects to make the oral contraceptive pill available without prescription in pharmacies.

To me - and I believe to many doctors - proposals to relax 'prescription-only' regulations seem eminently sensible. These drugs are essentially 'lifestyle' medications with clearly defined indications and wide margins of safety. If patients could get such drugs in pharmacies it would be more convenient for them and it would take some pressure off our already overburdened surgeries.

Yet some doctors are reluctant to forgo the opportunity for moralising health promotion that is offered by any request for a prescription in the surgery. An editorial on orlistat in the Lancet complained that patients would miss out on the 'holistic approach necessary in the management of all obese patients'. It neglected to mention that there is even less evidence of the efficacy of its preferred approach - 'long-term lifestyle changes' - than there is for taking orlistat.

In a 'head to head' debate on the OTC contraceptive pill in the BMJ, the women's health spokesperson of the RCGP was concerned that young women would evade evangelical GPs offering longacting reversible contraception (such as coils, injections and implants) in the crusade to deter teenage pregnancy. ${ }^{2}$ Leaving aside the question of whether GPs should involve themselves in a Malthusian campaign with distinctly eugenic undertones, the fact that the large majority of users of oral contraception are not teenagers was entirely ignored.

Now that the project of replacing capitalism with a more rational and equitable system of production - to which I devoted much time and energy in the past - is off the agenda and the market is the only show in town, its advocates are remarkably lacking in confidence in its mechanisms. This is dramatically evident in recent state intervention in the financial system, and it is also apparent in the relations between the NHS and the pharmaceutical industry, where market principles are distorted by monopoly and cartel, price-fixing and public subsidy, and an opaque regulatory framework.

Not only is there great resistance to making drugs available OTC, there is also fierce hostility to allowing direct advertising of pharmaceuticals to the public. But this simply reflects a combination of contempt for the capacity of people to make their own judgements about the value of medications and a paternalistic notion of protecting vulnerable consumers from the rapacious pharmaceutical corporations. One result of the excessive regulation of this area is the proliferation of 'disease-mongering' advertisements, with which drug companies 'raise awareness' of conditions from athlete's foot to erectile dysfunction, in the hope of luring patients into our surgeries to request the appropriate product.

Why not let the drug companies freely advertise these medications and the pharmacies sell them? Customers could then make their own choices and, in the ancient spirit of 'buyer beware', look out for the adverse effects. If people believe that dieting aids and birth control pills, or vitamins and Viagra, or statins and SSRIs, are a good bargain, let them buy them, just as they buy paracetamol and aspirin, beer and cigarettes, or any other commodity.

Those of us who consider that medical practice should be about the diagnosis and treatment of disease, rather than the regulation of lifestyles (with or without the aid of pharmaceuticals), would then have more time to get on with our work.

\section{REFERENCES}

1. Over-the-counter medicines: in whose best interests? Lancet 2009; 373: 354.

2. Should the contraceptive pill be available without prescription? BMJ 2009; 338: 202-203. http://www.bmj.com/cgi/section_pdf/337/dec23 2/a3044.pdf (accessed 3 Feb 2009).

DOI: 10.3399/bjgp09X420167 